\title{
A simplified method for the simultaneous detection of nervous necrosis virus and iridovirus in grouper Epinephelus spp.
}

\author{
N.-T. YU ${ }^{1,2 *}$, Y.-L. ZHANG ${ }^{1}$, Z. XIONG ${ }^{3}$ L. QU' ${ }^{1}$ Z.-X. LIU ${ }^{1 *}$
}

\begin{abstract}
${ }^{1}$ Institute of Tropical Bioscience and Biotechnology, Chinese Academy of Tropical Agricultural Sciences, Haikou, 571101, P. R. China; ${ }^{2}$ Institute of Hydrobiology, Chinese Academy of Sciences, University of Chinese Academy of Sciences, Wuhan 430072, P. R. China; ${ }^{3}$ School of Plant Sciences and BIO5 Institute, University of Arizona, Tucson, AZ 85721 USA
\end{abstract}

Received April 17, 2018; accepted May 30, 2018

\begin{abstract}
Summary. - Grouper nervous necrosis virus (GNNV) and grouper iridovirus (GIV) are major grouperinfecting viruses in southern China that can cause serious economic losses. A duplex reverse transcription-PCR (duplex RT-PCR) method was developed for the simultaneous detection of GNNV and GIV. Eight groups of primers specifically targeting the capsid protein genes of GNNV and GIV were designed and analyzed. The primer set GN4 was selected and used to amplify fragments of $887 \mathrm{bp}$ and $319 \mathrm{bp}$ in length from GNNV and GIV, respectively. Furthermore, the duplex PCR assay was shown to be sensitive because it could detect at least $20 \mathrm{pg}$ of plasmid-viral DNA from a mixture of viruses. Using this assay, $18 \mathrm{GNNV}$ infected groupers and 7 GIV infected groupers were detected amongst 41 suspected samples in Hainan. The duplex RT-PCR assay proved to be a rapid, specific, and sensitive method for detecting the two grouper viruses. This method could be used to facilitate better control of fish viruses through early detection.
\end{abstract}

Keywords: duplex reverse transcription-PCR; nervous necrosis virus; iridovirus; grouper

\section{Introduction}

Groupers (Epinephelus spp.) are valuable fish species in Asian aquaculture and widely distributed in eastern and southern areas of China (Chen et al., 2016). However, viral diseases caused by the grouper nervous necrosis virus (GNNV) and grouper iridovirus (GIV) have been reported across grouper production centers in China, Malaysia, Japan, Singapore, and elsewhere around Asia (Ransangan and Manin, 2012; Liu et al., 2012; Nishioka et al., 2017; Ma et al., 2016; Hazeri et al., 2016; Liu et al., 2016). GNNV and GIV are also major pathogens that can cause serious economic losses in Hainan, China (Ma et al., 2012). GNNV, of the family Nodaviridae and the genus Betanodavirus, is a small non-enveloped icosahedral virus containing bi-segmented single-stranded positive RNA as genetic material (Chien

*Corresponding authors. E-mail: yunaitong@163.com (N.-T. Yu); liuzhixin@itbb.org.cn (Z.-X. Liu); phone: +086-898-66890770.

Abbreviations: GNNV = grouper nervous necrosis virus; GIV = grouper iridovirus et al., 2017; Chérif et al., 2010). RNA1 encodes an RNAdependent RNA polymerase for viral replication while RNA2 encrypts a viral capsid protein (Chérif et al., 2010; Xu et al., 2010). GIV, of the family Iridoviridae and the genus Ranavirus, has an icosahedral symmetry and linear double-stranded DNA genome (Teng et al., 2008). A major capsid protein in GIV or Singapore grouper iridovirus (SGIV) was identified and characterized (Wan et al., 2010; Liu et al., 2015).

In recent years, a co-infection of these two agents have resulted in disease that can lead to a significant reduction in grouper production in Qionghai county, Hainan province, China (Ma et al., 2012). The most effective way to prevent the introduction of the disease into grouper production is to use healthy juvenile fish. Therefore, sensitive and reliable detection methods are urgently needed for the certification and quarantine programs of grouper propagation materials and for farm management. In situ hybridization (Huang et al., 2004), simplex RT-PCR (Cherif et al., 2011), loop-mediated isothermal amplification (LAMP) (Sung et al., 2010), immunomagnetic reduction (IMR) (Lu et al., 2016), enzyme-linked apta-sorbent assay (ELASA) (Li et 
Table 1. Specific primers designed from GNNV capsid protein gene and GIV capsid protein gene

\begin{tabular}{|c|c|c|c|}
\hline Virus & Primer name & Sequence $\left(5^{\prime}-3^{\prime}\right)$ & $\operatorname{Tm}\left(50 \mathrm{mmol} / \mathbf{l} \mathrm{Na}^{+}\right)$ \\
\hline \multirow[t]{7}{*}{ GNNV } & NNV-CPF & CCATCACCGCTTTGCAATCAC & 49.2 \\
\hline & NNV-CPR & CTAGGGAACCGGATGACCCG & 52.8 \\
\hline & NNV-CPF2 & TCCATCACCGCTTTGCAATCACA & 50.2 \\
\hline & NNV-CPR2 & CACTAGGGAACCGGATGACCCG & 55.3 \\
\hline & NNV-CPF3 & CAATGGTACGCAAAGGTGAGAAG & 50.2 \\
\hline & NNV-CPR3 & CACTAGGGAACCGGATGACCC & 53.1 \\
\hline & NNV-CPF4 & CCAATGACGTCCATCTCTCAGGTATG & 54.4 \\
\hline \multirow[t]{3}{*}{ GIV } & GIV-CP211F & CCCAGGTCGGGCGATTACGTG & 55.1 \\
\hline & GIV-CP287F & GGCTCGGCGCAAACGGTACC & 54.8 \\
\hline & GIV-CP605R & GGCAACACTACGGTGGGCAGAG & 55.3 \\
\hline
\end{tabular}

Table 2. Eight grouped primers of GNNV and GIV for duplex RT-PCR

\begin{tabular}{|c|c|c|c|c|}
\hline Group & NNV forward primer & NNV reverse primer & GIV forward primer & GIV reverse primer \\
\hline GN1 & NNV-CPF & NNV-CPR & \multirow{4}{*}{ GIV-CP287F } & \multirow{4}{*}{ GIV-CP605R } \\
\hline GN2 & NNV-CPF2 & NNV-CPR2 & & \\
\hline GN3 & NNV-CPF3 & NNV-CPR3 & & \\
\hline GN4 & NNV-CPF4 & NNV-CPR3 & & \\
\hline GN5 & NNV-CPF & NNV-CPR & \multirow{4}{*}{ GIV-CP211F } & \multirow{4}{*}{ GIV-CP605R } \\
\hline GN6 & NNV-CPF2 & NNV-CPR2 & & \\
\hline GN7 & NNV-CPF3 & NNV-CPR3 & & \\
\hline GN8 & NNV-CPF4 & NNV-CPR3 & & \\
\hline
\end{tabular}

al., 2016), and real-time PCR (Kim et al., 2016) methods are applied to diagnose these diseases frequently. However, these molecular techniques are based on the detection of different pathogens using different species-specific targeting genes and not performed simultaneously in a single tube of reaction. As the mixed infection of two or more pathogens is common in groupers, a test that could detect multiple pathogens simultaneously would be ideal for routine disease diagnosis and quarantine. Duplex or multiplex RT-PCR is a rapid and convenient screening assay to simultaneously amplify different targets in one single reaction tube. This would save reagents, time, and costs (Binkhamis et al., 2017; Soares et al., 2005; Skorvaga et al., 2014; Peiman and Xie, 2006; Yoganandhan et al., 2005). To the best of our knowledge, published duplex assays for detection and differentiation of grouper viruses are very limited. Therefore, the aim of this study was to develop the duplex RT-PCR for simultaneous detection of GNNV and GIV viruses in clinical samples. Our results indicated that the assay developed in this study was a useful method for identifying viruses in specimens from groupers with co-infections and could be used in high throughput screenings for grouper viruses and disease management programs.

\section{Materials and Methods}

Viruses and materials. GIV infected grouper fingerlings $(2 \sim 3 \mathrm{~cm}$ in body length) were kept at the Institute of Tropical Bioscience and Biotechnology of the Chinese Academy of Tropical Agricultural Sciences, and total DNA was extracted by using MiniBEST Universal genomic DNA extraction kit Ver.5.0 (Takara, China). The full-length of GNNV RNA2 (GenBank Acc. No. KM095959) was synthesized and inserted into a pUC57 vector using Xba I and Hind III (General Biosystems, Inc., China). These materials, total

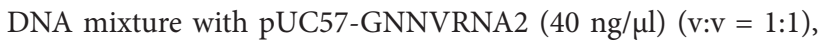
were used as standards for the optimization of the duplex PCR and maintained at $-20^{\circ} \mathrm{C}$ until testing. During the year of 2015 to 2016, grouper fingerlings suspected of viral infection with abnormal swimming and/or gill hemorrhage symptoms were collected from eastern seaboard farms of Hainan province in China and were tested to validate the efficiency of the optimized duplex RT-PCR method.

Primer design and simplex PCR test. Specific primers for the conserved region of the GIV capsid protein gene were designed according to the reference sequence of GIV isolate Tn_352_05 (GenBank Acc. No. JF264358) and GIV isolate SY1301 (GenBank Acc. No. KX284838). Specific primers for the coding region of the GNNV capsid protein gene were designed from the full-length sequences of GNNV RNA2 (GenBank Acc. No. KM095959). All 

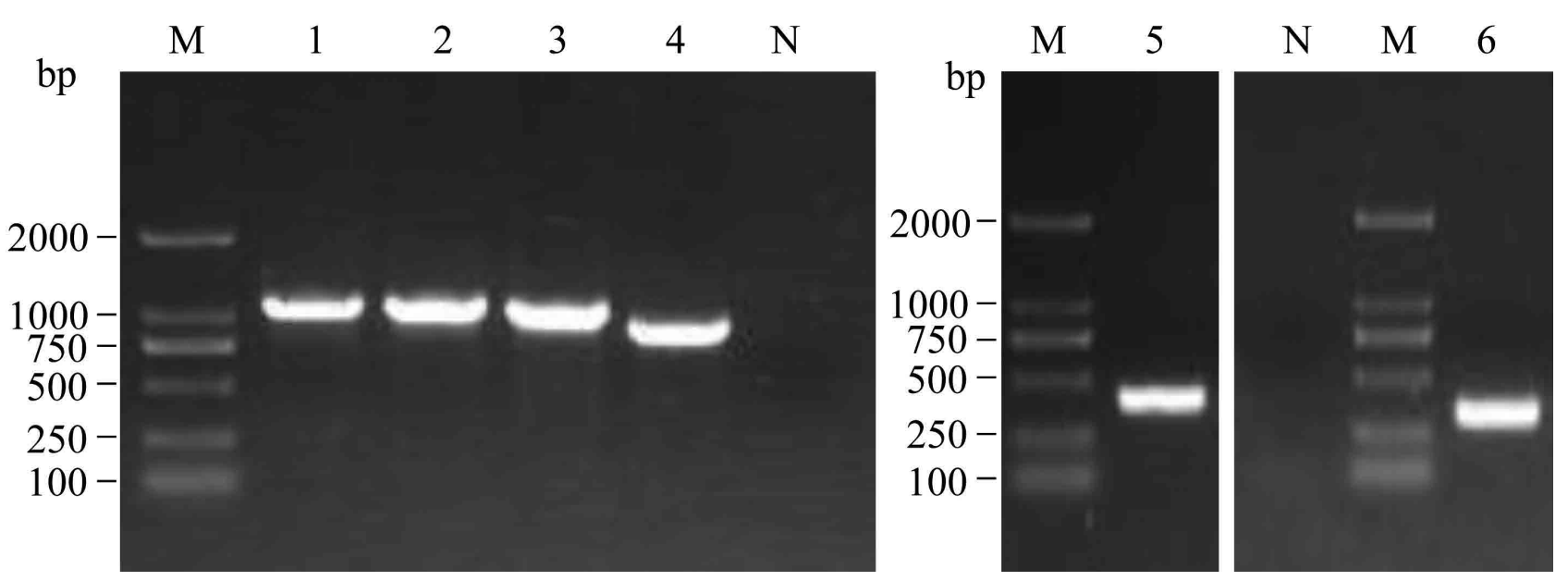

Fig. 1

Specific PCR amplification using the GNNV primers and GIV primers

Lane M: Trans 2000 bp DNA marker. PCR products amplified using primers: lane 1: GNNV-CP F/R; lane 2: GNNV-CP F2/R2; lane 3: GNNV-CP F3/R3; lane 4: GNNV-CP F4/R3; lane 5: GIV-CP211F/605R; lane 6: GIV-CP287F/605R. Lane N: negative control.

the primers are listed in Table 1. To differentiate the two viruses, primers were optimized to obtain PCR product sizes with a difference of more than $400 \mathrm{bp}$. The primers selected for the specific detection of GNNV were CP F/R (1061 bp), CP F2/R2 (1064 bp), CP F3/R3 (1043 bp), and CP F4/R3 (887 bp). The primers selected for the specific detection of GIV were CP211F/605R (395 bp) and CP287F/605R (319 bp). These primers were used to perform confirmatory tests in simplex PCR. For simplex PCR, a $25 \mu$ reaction solution including $1 \mu \mathrm{l}$ of DNA, $12.5 \mu \mathrm{l}$ of SinoBio $2 \mathrm{X}$ master mix (SinBio, China), $1 \mu \mathrm{l}$ of $\mathrm{F} / \mathrm{R}$ primers $(5 \mu \mathrm{mol} / \mathrm{l})$, and $10.5 \mu \mathrm{l}$ of $\mathrm{ddH}_{2} \mathrm{O}$ was used. The PCR program was set to $95^{\circ} \mathrm{C}$ for $2 \mathrm{~min}$, followed by 35 cycles at $94^{\circ} \mathrm{C}$ for $30 \mathrm{~s}, 55^{\circ} \mathrm{C}$ for $30 \mathrm{~s}, 72^{\circ} \mathrm{C}$ for $1 \mathrm{~min}$, and a final extension at $72^{\circ} \mathrm{C}$ for $10 \mathrm{~min}$. PCR products were analyzed on $1 \%$ agarose gel and were further cloned into the pMD18-T vector (Takara, China). The positive clones were sequenced and confirmed by sequencing.

Optimization of duplex PCR. The duplex PCR assay was optimized to maximize simultaneous amplification of the targeted CP gene fragments for GNNV and GIV in clinical samples. Eight grouped primers of GN1 to GN8 were used for the optimization (Table 2). Concentrations of the primers and annealing temperatures were also optimized. The concentrations of the $\mathrm{F} / \mathrm{R}$ primers $0.1,0.2,0.4$, and $0.8 \mu \mathrm{mol} / 1$ were test. The annealing temperatures $45.0,45.5,47.5,50.0,53.0,56.0,58.0,61.0,64.0,66.5,68.5$, and $70.0^{\circ} \mathrm{C}$ were test. The mixed template and dilution templates of $1: 10,1: 50,1: 100,1: 500,1: 10^{3}, 1: 5 \times 10^{3}, 1: 10^{4}, 1: 10^{5}$, and $1: 10^{6}$ were tested. The PCR reactions were carried out as described above, but the concentrations of the primers and annealing temperatures varied.

Sensitivity detection of duplex PCR. In order to perform a sensitive assay for GNNV and GIV using the optimized duplex
PCR method, the recombinant plasmid pMD18T-GIVCP was constructed from the fragment of CP287F/605R. The pUC57GNNVRNA2 (400 ng/ $\mu \mathrm{l})$ and pMD18T-GIVCP (250 ng/ $\mu$ l) were mixed in a ratio of $1: 1(\mathrm{v}: \mathrm{v})$. Then, the mixed template and the template dilutions of $1: 10,1: 50,1: 100,1: 500,1: 10^{3}, 1: 5 \times 10^{3}, 1: 10^{4}$, $1: 10^{5}$, and $1: 10^{6}$ were used to determine the sensitivity of the assay using the optimized duplex RT-PCR.

Total RNA extraction and duplex RT-PCR detection of diseased samples. Total RNA was extracted from grouper heads (including brain and gill) with the TRIzol reagent (Ambion, Life technology, USA) according to the manufacture's protocol. First-strand cDNA was synthesized from $2.0 \mu \mathrm{l}$ of total RNA using $0.5 \mu \mathrm{l}$ of random hexamer primer $(10 \mu \mathrm{mol} / \mathrm{l}), 0.5 \mu \mathrm{l}$ of OligodT $(10 \mu \mathrm{mol} / \mathrm{l})$ and $0.5 \mu \mathrm{l}$ M-MLV reverse transcriptase (200 U/ $\mu$ l, Promega, USA) at $42^{\circ} \mathrm{C}$ for $30 \mathrm{~min}$. These samples were then amplified using the optimized duplex RT-PCR.

\section{Results}

\section{Simplex PCR test}

PCR amplified products of $1061 \mathrm{bp}$ (CP F/R), $1064 \mathrm{bp}$ (CP F2/R2), 1043 bp (CP F3/R3), and 887 bp (CP F4/R3) corresponding to the expected target GNNV CP genes were obtained using the simplex PCR (Fig. 1, lanes 1-4). Meanwhile, 395 bp (CP211F/605R) and 319 bp (CP287F/605R) DNA fragments of GIV CP gene partial sequences were also obtained (Fig. 1, lanes 5-6). The primers in the simplex assays showed specificity for the respective viruses, and no amplification occurred in the negative control. 

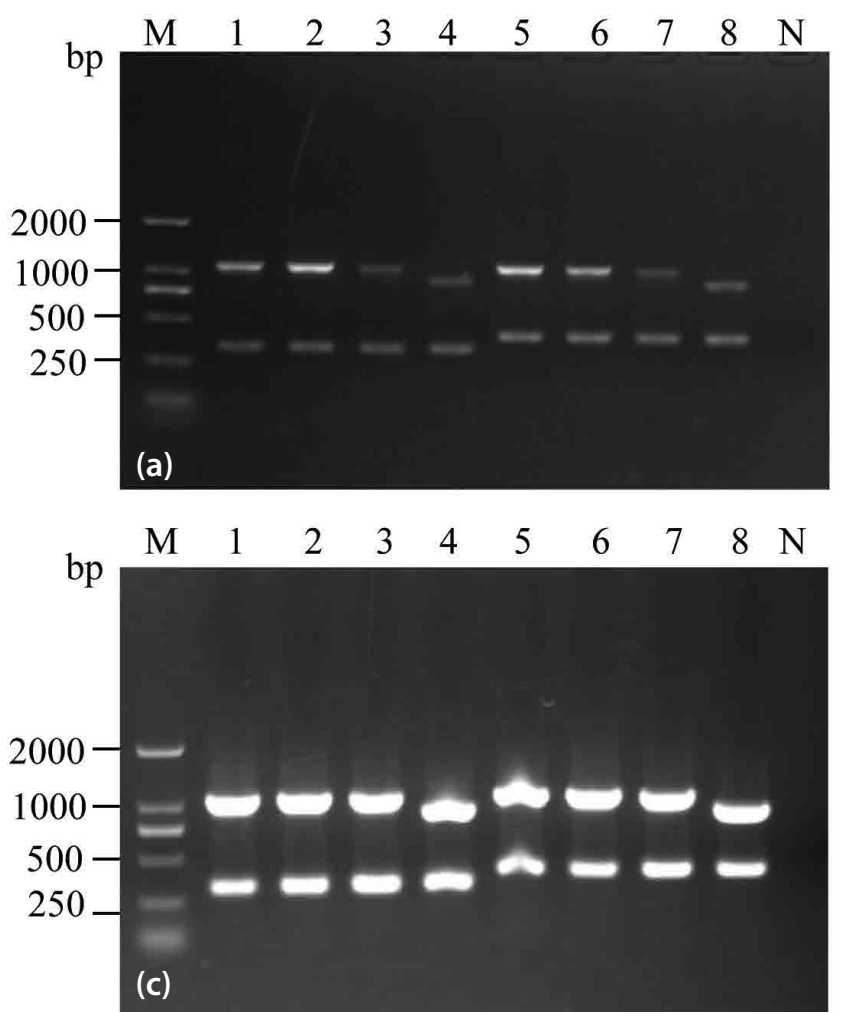
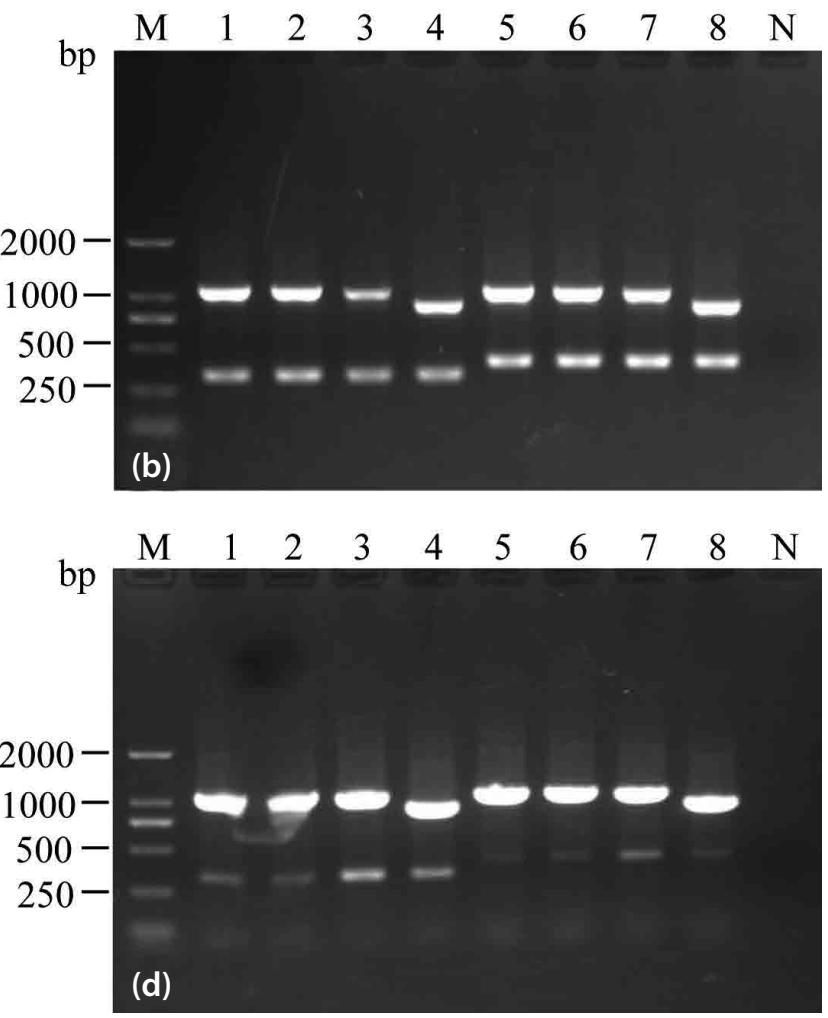

Fig. 2

Optimization of duplex RT-PCR for GNNV and GIV using the different concentrations of GN1 to GN8 grouped primers Lane M: Trans 2000 bp DNA marker; lane 1: GN1 group; lane 2: GN2 group; lane 3: GN3 group; lane 4: GN4 group; lane 5: GN5 group; lane 6: GN6 group; lane 7: GN7 group; lane 8: GN8 group; lane N: negative control. (a) $0.1 \mu \mathrm{mol} / \mathrm{l}$ of GN1 to GN8 grouped primers; (b) $0.2 \mu \mathrm{mol} / \mathrm{l}$ of GN1 to GN8 grouped primers; (c) $0.4 \mu \mathrm{mol} / 1$ of GN1 to GN8 grouped primers; (d) $0.8 \mu \mathrm{mol} / \mathrm{l}$ of GN1 to GN8 grouped primers.

\section{Optimization of duplex PCR conditions}

To determine the optimum concentration of GN1 to GN8 grouped primers for GNNV and GIV, different concentrations were tested in the same reaction containing total DNA of GIV-infected grouper and pUC57-GNNVRNA2
(40 ng/ $\mu \mathrm{l})$ as templates. The optimum concentration of primers specific to both GNNV and GIV were determined to be at $0.4 \mu \mathrm{mol} / \mathrm{l}$ (Fig. 2). A gradient temperature test was conducted to determine the optimal annealing temperature in the duplex PCR. Results showed that GN3, GN4 and GN8 group primers performed well at annealing temperature

Table 3. Optimization of duplex RT-PCR for GNNV and GIV using annealing temperature of $45-70^{\circ} \mathrm{C}$

\begin{tabular}{|c|c|c|c|c|c|c|c|c|c|c|c|c|}
\hline \multirow{2}{*}{ Primer group } & \multicolumn{12}{|c|}{ Annealing temperature $\left({ }^{\circ} \mathrm{C}\right)$} \\
\hline & 45.0 & 45.5 & 47.5 & 50.0 & 53.0 & 56.0 & 58.0 & 61.0 & 64.0 & 66.5 & 68.5 & 70.0 \\
\hline GN1 & + & + & + & + & + & + & + & + & + & - & - & - \\
\hline GN2 & ++ & ++ & ++ & ++ & ++ & ++ & ++ & ++ & ++ & ++ & $+/-$ & $+/-$ \\
\hline GN3 & +++ & +++ & +++ & +++ & +++ & +++ & +++ & +++ & + & - & - & - \\
\hline GN4 & +++ & +++ & +++ & +++ & +++ & +++ & +++ & +++ & +++ & - & - & - \\
\hline GN5 & ++ & ++ & ++ & ++ & ++ & ++ & ++ & ++ & ++ & ++ & $+/-$ & - \\
\hline GN6 & + & + & + & + & + & + & + & + & + & + & + & + \\
\hline GN7 & + & + & + & + & + & + & + & + & + & + & + & $+/-$ \\
\hline GN8 & +++ & +++ & +++ & +++ & +++ & +++ & +++ & +++ & +++ & +++ & $+/-$ & - \\
\hline
\end{tabular}

“+” represents the amount of DNA fragments. The number of fragments is representatively ranked as “+++”> “++”>“+” “-” represents the negative result. 
Table 4. Optimization of duplex RT-PCR for GNNV and GIV using different concentrations of the template

\begin{tabular}{|c|c|c|c|c|c|c|c|c|c|c|c|c|}
\hline \multirow{2}{*}{ Primers group } & \multicolumn{12}{|c|}{ Template dilution } \\
\hline & 1 & $1: 10$ & $1: 50$ & $1: 100$ & $1: 500$ & $1: 10^{3}$ & $1: 5 \times 10^{3}$ & $1: 10^{4}$ & $1: 5 \times 10^{4}$ & $1: 10^{5}$ & $1: 10^{6}$ & $\mathrm{dH}_{2} \mathrm{O}$ \\
\hline GN3 & ++ & ++ & ++ & ++ & + & + & - & - & - & - & - & - \\
\hline GN4 & ++ & ++ & ++ & ++ & ++ & + & + & - & - & - & - & - \\
\hline GN8 & ++ & ++ & ++ & ++ & ++ & ++ & $+1-$ & - & - & - & - & - \\
\hline
\end{tabular}

“+” represents the amount of DNA fragments. The number of fragments is representatively ranked as “++”> “+” “-” represents the negative result.

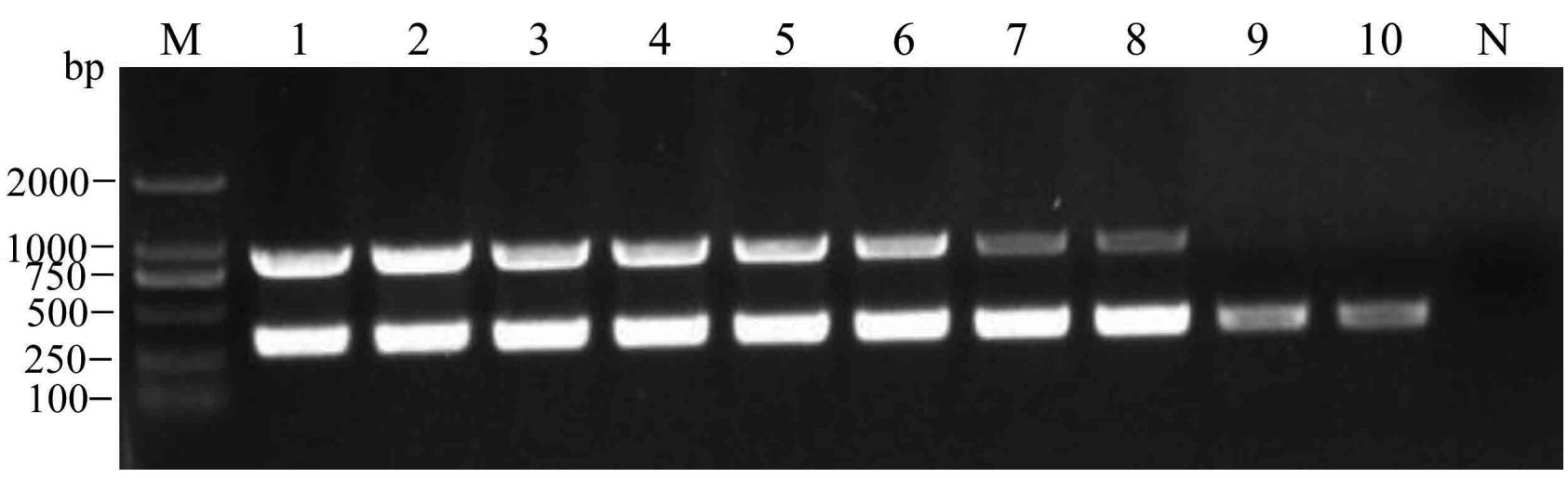

Fig. 3

Sensitive assay of duplex RT-PCR of the diluted plasmid mixture using GN4 grouped primers

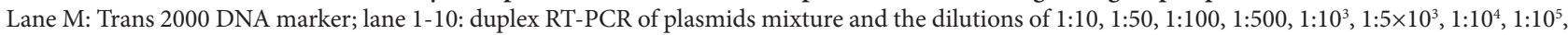
and $1: 10^{6}$; lane $\mathrm{N}$ : negative control.

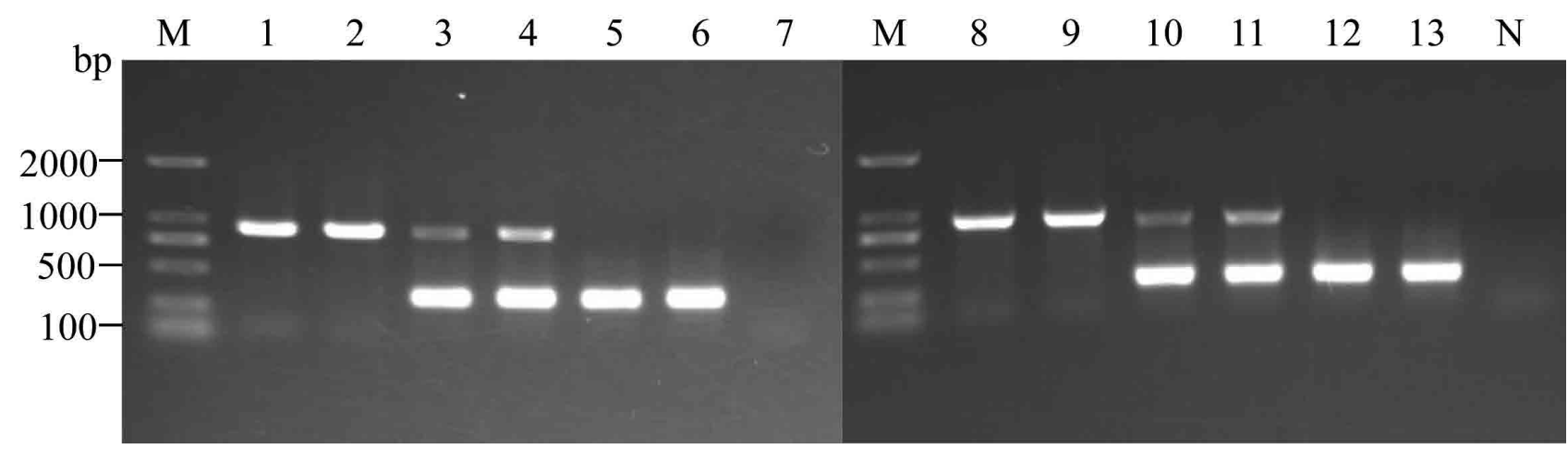

Fig. 4

Simultaneous detection of GNNV and GIV in the mixed samples using the optimized duplex RT-PCR with GN4 grouped primers Lane M: Trans2k DNA Marker; lane 1: $1 \mathrm{~J}$ cDNA; lane 2: $\mathrm{J} \mathrm{cDNA}$; lane 3: $1 \mathrm{~J}$ and $7 \mathrm{~K}$ cDNA (v:v = 1:1); lane 4:2J and 8K cDNA (v:v = 1:1); lane 5: 7K cDNA; lane 6: 8K cDNA; lane 7: $\mathrm{dH} 2 \mathrm{O}$; lane 8: 3J cDNA; lane 9: 4J cDNA; lane 10: 3J and 11K cDNA (v:v=1:1); lane 11:4J and 17K cDNA (v:v=1:1); lane 12: $11 \mathrm{~K}$ cDNA; lane 13: 17K cDNA; lane N: $\mathrm{dH}_{2} \mathrm{O}$. Note: 1J (15-10-SBY-LD-1J-421), 2J (15-10-SBY-LD-2J-421), 3J (15-10-SBY-LD-3J-421), 4J (15-10-SBYLD-4J-421), 7K (SBY-7K), 8K (SBY-8K), 11K (SBY-11K), and 17K (SBY-17K).

ranging from 45 to $61^{\circ} \mathrm{C}$. The GN8 group also performed better than other two groups (Table 3 ). In the study, the optimum annealing temperature of $53^{\circ} \mathrm{C}$ was selected for the duplex PCR. The limit of the template concentration was analyzed from the mixed template and the dilutions of $1: 10,1: 50,1: 100,1: 500,1: 10^{3}, 1: 5 \times 10^{3}, 1: 10^{4}, 1: 10^{5}$, and $1: 10^{6}$.
The results showed that no DNA fragments were obtained beyond a dilution of $1: 5 \times 10^{3}$ or more (Table 4 ). Furthermore, no significant primer interaction or primer-dimer formation was observed from these analyses.

In summary, the optimal reactions were shown to occur using a $0.4 \mu \mathrm{mol} / \mathrm{l}$ of each primer, $1 \mu \mathrm{l}$ of mixed templates, 
Table 5. Summary of the detection results of 41 suspected virus-infected groupers using optimized duplex RT-PCR

\begin{tabular}{clcc}
\hline No. & Sample & NNV & GIV \\
\hline 1 & $15-2-$ SBY-Lu-3b & - & - \\
2 & $15-2-S B Y-L u-4 b$ & - & - \\
3 & $15-2-S B Y-l i u-5 b$ & - & - \\
4 & $15-2-S B Y-l i u-6 b$ & - & - \\
5 & $15-5-S B Y-c a i-1 e$ & - & - \\
6 & $15-5-S B Y-c a i-3 e$ & - & - \\
7 & $15-5-S B Y-c a i-6 e$ & - & - \\
8 & $15-5-S B Y-c a i-7 e$ & - & - \\
9 & $15-5-S B Y-c a i-11 e$ & + & - \\
10 & $15-5-S B Y-c a i-12 e$ & - & - \\
11 & $15-6-S B Y-D o n g-8 f$ & + & - \\
12 & $15-7-S B Y-2 g$ & + & - \\
13 & $15-7-S B Y-c a i-6 g$ & - & - \\
14 & $15-7-S B Y-c a i-8 g$ & + & - \\
15 & $15-10-S B Y-L D-1 J-421$ & + & - \\
16 & $15-10-S B Y-L D-2 J-421$ & + & - \\
17 & $15-10-S B Y-L D-3 J-421$ & + & - \\
18 & $15-10-S B Y-L D-4 J-421$ & + & - \\
19 & $15-11-S B Y-x i e j u n-4 K$ & + & - \\
20 & $15-11-G S Y-h u i w e n d i a n-13 K$ & + & - \\
21 & $15-14-S B Y-x i a o-6 n$ & + & - \\
\hline
\end{tabular}

\begin{tabular}{|c|c|c|c|}
\hline No. & Sample & NNV & GIV \\
\hline 22 & 15-P-SBY -6P & - & - \\
\hline 23 & 15-P-SBY -7P & + & - \\
\hline 24 & $15-\mathrm{R}-1$ & - & - \\
\hline 25 & $15-\mathrm{R}-2$ & - & - \\
\hline 26 & $15-\mathrm{R}-3$ & - & - \\
\hline 27 & $15-\mathrm{V}-\mathrm{LD}-4 \mathrm{~V}$ & + & - \\
\hline 28 & 15-V-LD-3V & + & - \\
\hline 29 & $15-\mathrm{X}-1$ & + & - \\
\hline 30 & $15-\mathrm{X}-2$ & + & - \\
\hline 31 & 15-Z-SBY-2016-Litie1d & + & - \\
\hline 32 & 15-Z-SBY-2016-Litie2d & - & - \\
\hline 33 & 16-SBY-WGX-3f & + & - \\
\hline 34 & 16-SBY-WGX-4f & + & - \\
\hline 35 & SBY-17K & - & + \\
\hline 36 & SBY-11K & - & + \\
\hline 37 & SBY-8K & - & + \\
\hline 38 & SBY-7K & - & + \\
\hline 39 & SBY-LD-4V & - & + \\
\hline 40 & SBY-16-9f & - & + \\
\hline 41 & SBY-16-10f & - & + \\
\hline
\end{tabular}

“+” represents the positive result, while “-” represents the negative result.

and $12.5 \mu$ l of SinoBio $2 x$ master mix (SinBio). The optimized duplex RT-PCR program was performed at $94^{\circ} \mathrm{C}$ for $2 \mathrm{~min}$, followed by 35 cycles of denaturation at $94^{\circ} \mathrm{C}$ for $30 \mathrm{~s}$, annealing at $53^{\circ} \mathrm{C}$ for $30 \mathrm{~s}$, and extension at $72^{\circ} \mathrm{C}$ for $1 \mathrm{~min}$, with a final extension at $72^{\circ} \mathrm{C}$ for $10 \mathrm{~min}$.

\section{Sensitivity of duplex PCR assay}

To evaluate the sensitivity of the duplex PCR assay, the mixed recombinant plasmids of pUC57-GNNVRNA2 (200 $\mathrm{ng} / \mu \mathrm{l})$ and pMD18T-GIVCP $(125 \mathrm{ng} / \mu \mathrm{l})$ were tested by using serial dilutions (from 1 to $10^{-6}$ ). As shown in Figure 3, the detection limits of the duplex PCR assays were $10^{-4}$ of GNNV, and $10^{-6}$ of GIV, respectively. The results indicated that the duplex PCR was able to detect at least $0.125 \mathrm{pg}$ of pMD18T-GIVCP, but only 20 pg of pUC57-GNNVRNA2.

\section{Duplex RT-PCR detection of diseased samples}

Forty-one clinical grouper samples suspected of virus infections were collected from the eastern farms of the Hainan province of China and were analyzed using the duplex RT-PCR and simplex RT-PCR. The duplex RT-PCR results identified 18 of GNNV infected groupers and 7 of GIV infected groupers (Table 5). All PCR products were sequenced to validate the specificity, and the result was identical to the duplex RT-PCR. Co-infection with the two viruses was not detected in these clinical samples. Furthermore, the identical detection results obtained by simplex RT-PCR indicated that the optimized duplex RT-PCR was fit for the purpose of field sample detection.

Lastly, in order to simulate all possible situations of virus infection in the field, artificial mixtures of cDNAs from the different virus infected groupers positive for GNNV and GIV were tested. The results confirmed that the developed duplex RT-PCR could amplify all possible combinations of viruses specifically and effectively (Fig. 4).

\section{Discussion}

GNNV and GIV are the most economically important viruses infecting groupers in Hainan. It is important to test them in grouper propagation materials. In this study, a duplex RT-PCR assay was developed for simultaneous detection of the two viruses in groupers. The duplex RT-PCR assay allowed simultaneous detection and differentiation of both types of pathogens in one reaction. This would reduce the time and cost of screening healthy propagation materials for groupers. Designing and selecting suitable primers is a critical step in setting up an efficient duplex RT-PCR reaction. Four pair-primers of GNNV and two pair-primers of GIV were designed based on the conserved regions of the capsid protein gene. The optimized primer group (GN4) in this duplex 
RT-PCR assay produced products with the expected sizes of 887 bp and 319 bp specific for GNNV and GIV, respectively.

This was also a pioneer attempt to detect RNA virus and DNA virus simultaneously in a duplex RT-PCR assay. GIV is a DNA virus but it produces active mRNA transcripts during infection. One simple RNA extraction from the clinical samples yielded RNA materials derived from both the GNNV viral genome and GIV transcripts. A simple reverse transcription step converted RNA from both the RNA virus and the DNA virus into single stranded DNA for the duplex PCR. Our work showed that it is feasible to detect DNA and RNA viruses simultaneously in one reaction.

In recent years, infection with GNNV and GIV is not uncommon in the groupers of Southern China, including Hainan Provinces (Ma et al., 2012). Therefore, a rapid and precise diagnostic detection is essential for early detection, surveillance, and prevention of disease spread. Duplex or multiplex RT-PCR has been verified as a rapid and convenient screening assay to simultaneously amplify different targets in one single reaction tube. This would save reagents, time, and costs. In the present study, the viral RNA was extracted simultaneously and subjected to the duplex RT-PCR reaction. The examination of 41 clinical samples using duplex RT-PCR indicated that $61 \%$ of the samples were infected with GNNV or GIV virus. Although co-infection of the two viruses were not detected in these clinical samples, this method should be able to monitor the epidemics of GNNV and GIV simultaneously. This report has described a cost effective and time saving method for diagnosis, screening, and surveillance of these viruses.

Acknowledgments. This research was supported by the National Nonprofit Institute Research Grant of CATAS (1630052016014), the Major Science and Technology Program of Hainan Province (grant No. ZDKJ2017003) and the Young Elite Scientists Sponsorship Program by CSTC (Project No. CSTC-QN201704).

\section{References}

Binkhamis K, Gillis H, Lafreniere JD, Hiebert J, Mendoza L, Pettipas J, Severini A, Hatchette TH, LeBlanc JJ (2017): Comparison of monoplex and duplex RT-PCR assays for the detection of measles virus. J. Virol. Methods 239, 58-60. https://doi.org/10.1016/j.jviromet.2016.11.003

Chen TS, Wu YC, Chi SC (2016): Decreasing salinity of seawater moderates immune response and increases survival rate of giant groupers post betanodavirus infection. Fish Shellfish Immunol. 57, 325-334. https://doi.org/10.1016/j. $\underline{\text { fsi.2016.08.050 }}$

Chérif N, Gagne N, Groman D, Kibenge F, Iwamoto T, Yason C, Hammami S (2010): Complete sequencing of Tunisian redspotted grouper nervous necrosis virus betanodavirus capsid gene and RNA-dependent RNA polymerase gene.
J. Fish Dis. 33, 231-240. https://doi.org/10.1111/j.13652761.2009.01116.x

Cherif N, Lopez-Jimena B, Garcia-Rosado E, Cano I, Castro D, Borrego JJ, Alonso MC, Hammami S (2011): Detection of SJNNV and RGNNV genotypes using a relative quantification RT-PCR assay. J. Appl. Ichthyol. 27, 805-812. https://doi.org/10.1111/j.1439-0426.2010.01592.x

Chien MH, Vo T, Wu SY, Lin CH (2017): Complete genome sequence of nervous necrosis virus isolated from orangespotted grouper (Epinephelus coioides) in Taiwan. Genome Announc. 5, e00942-17. https://doi.org/10.1128/ genomeA.00942-17

Hazeri M, Hassan MD, Abba Y, Omar AR, Allaudin ZN, Soltani M, Hamdan RH, Mohamad NFA, Vishkaei MS (2016): Histopathological evaluation and molecular detection of natural Iridovirus infection in cultured grouper fish in Malaysia. Comp. Clin. Pathol. 25, 965-971. https://doi. org/10.1007/s00580-016-2288-Z

Huang C, Zhang X, Gin KY, Qin QW (2004): In situ hybridization of a marine fish virus, Singapore grouper iridovirus with a nucleic acid probe of major capsid protein. J. Virol. Methods 117, 123-128. https://doi.org/10.1016/j. jviromet.2004.01.002

Kim JO, Kim JO, Kim WS, Oh MJ (2016): Development and application of quantitative detection method for nervous necrosis virus (NNV) isolated from sevenband grouper Hyporthodus septemfasciatus. Asian Pac. J. Trop. Med. 9, 742-748. https://doi.org/10.1016/j.apjtm.2016.06.014

Li P, Zhou L, Wei J, Yu Y, Yang M, Wei S, Qin Q (2016): Development and characterization of aptamer-based enzyme-linked apta-sorbent assay for the detection of Singapore grouper iridovirus infection. J. Appl. Microbiol. 121, 634-643. https://doi.org/10.1111/jam.13161

Liu H, Teng Y, Zheng X, Wu Y, Xie X, He J, Ye Y, Wu Z (2012): Complete sequence of a viral nervous necrosis virus $(\mathrm{NNV})$ isolated from red-spotted grouper (Epinephelus akaara) in China. Arch. Virol. 157, 777-782. https://doi. org/10.1007/s00705-011-1187-5

Liu HI, Chiou PP, Gong HY, Chou HY (2015): Cloning of the major capsid protein (MCP) of grouper iridovirus of Taiwan (TGIV) and preliminary evaluation of a recombinant MCP vaccine against TGIV. Int. J. Mol. Sci. 16, 28647-28656. https://doi.org/10.3390/ijms161226118

Liu P, Wang L, Kwang J, Yue GH, Wong SM (2016): Transcriptome analysis of genes responding to NNV infection in Asian seabass epithelial cells. Fish Shellfish Immunol. 54, 342-352. https://doi.org/10.1016/j.fsi.2016.04.029

Lu MW, Kuo HP, Chou HY, Ling EY, Chung CL, Hung YF, Horng HE, Wu JL, Her GM, Kong ZL (2016): A novel method for detection of fish iridovirus in groupers using nanomagnetic particles. Fish Pathol. 51, S54-S59. https://doi. org/10.3147/jsfp.51.S54

Ma H, Peng C, Su Y, Feng J, Guo Z (2016): Isolation of a ranavirus -type grouper iridovirus in mainland China and comparison of its pathogenicity with that of a megalocytivirus -type grouper iridovirus. Aquaculture 463, 145-151. https://doi.org/10.1016/j.aquaculture.2016.05.032 
Ma H, Xie J, Weng S, Zhou T, He J (2012): Co-infection of megalocytivirus and viral nervous necrosis virus in a very severe mass mortality of juvenile orange-spotted groupers (Epinephelus coioides). Aquaculture 358-359, 170-175. https://doi.org/10.1016/j.aquaculture.2012.06.032

Nishioka T, Sugaya T, Kawato Y, Mori KI, Nakai T (2017): Pathogenicity of striped jack nervous necrosis virus (SJNNV) isolated from asymptomatic wild japanese jack mackerel (trachurus japonicus). Fish Pathol. 51, 176-183. https:// doi.org/10.3147/jsfp.51.176

Peiman M, Xie C (2006): Development and evaluation of a multiplex RT-PCR for detecting main viruses and a viroid of potato. Acta Virol. 50, 129-133.

Ransangan J, Manin BO (2012): Genome analysis of betanodavirus from cultured marine fish species in malaysia. Vet. Microbiol. 156, 16-44. https://doi.org/10.1016/j. vetmic.2011.10.002

Skorvaga M, Nikitina E, Kolenova A, Puskacova J, Leitnerova M, Copakova L, Belyaev I (2014): Combined multiplex and monoplex RT-PCR as a reliable and cost-effective method for molecular diagnostics of pediatric acute lymphoblastic leukemia. Neoplasma 61, 758-765. https://doi. org/10.4149/neo 2014092

Soares PBM, Demétrio C, Sanfilippo L, Kawanoto AHN, Brentano L, Durigon EL (2005): Standardization of a duplex RT-PCR for the detection of Influenza A and Newcastle disease viruses in migratory birds. J. Virol. Methods 123 , 125-130. https://doi.org/10.1016/j.jviromet.2004.09.011 Sung CH, Chi SC, Huang KC, Lu JK (2010): Rapid detection of grouper iridovirus by loop-mediated isothermal amplification. J. Marine Sci. Tech., 18, 568-573.

Teng Y, Hou Z, Gong J, Liu H, Xie X, Zhang L, Chen XH, Qin QW (2008): Whole-genome transcriptional profiles of a novel marine fish iridovirus, Singapore grouper iridovirus (SGIV) in virus-infected grouper spleen cell cultures and in orange-spotted grouper, Epinephulus coioides. Virology 377, 39-48. https://doi.org/10.1016/j. virol.2008.04.011

Wan QJ, Gong J, Huang XH, Huang YH, Zhou S, Ou-Yang ZL, Cao JH, Ye LL, Qin QW (2010): Identification and characterization of a novel capsid protein encoded by Singapore grouper iridovirus ORF038L. Arch. Virol. 155, 351-359. https://doi.org/10.1007/s00705-010-0594-3

Xu HD, Ou YJ, Guo ZX, Su YL, Wang RX (2010): The pathogenicity of nervous necrosis virus to trachinotus ovatus and sequence analysis of the coat protein gene. J. Shanghai Ocean Univ. 19, 482-488.

Yoganandhan K, Sri Widada J, Bonami JR, Sahul Hameed AS (2005): Simultaneous detection of Macrobrachium rosenbergii nodavirus and extra small virus by a single tube, one-step multiplex RT-PCR assay. J. Fish Dis. 28, 65-69. https://doi.org/10.1111/j.1365-2761.2004.00606.x 